\title{
EFFECT OF IRRIGATION LEVELS AND FOLIAR SPRAYING WITH SEAWEED EXTRACT, POTASSIUM SILICATE AND ABSCISIC ACID ON GROWTH, CORM YIELD AND QUALITY OF TARO
}

\author{
Amira M.M. Abuzeed ${ }^{1 *}$, M.E. Ragab ${ }^{2}$, S.A. Abd Elhady ${ }^{2}$ \\ and Zahra A.A. El-Sharkawy ${ }^{1}$ \\ 1- Potato and Vegetatively Propagated Vegetable Dept., Horticulture Research Institute, Agric. \\ Research Center, Giza, Egypt \\ 2- Horticulture Dept., Fac. of Agric., Ain Shams Univ. P.O. Box 68, Hadayek Shobra 11241, \\ Cairo, Egypt \\ *Corresponding author: amiromay@yahoo.com
}

Accepted 22 July, 2018

\begin{abstract}
The field experiment was established at the experimental farm of the Horticultural Research Station of Barrage, Qalyubia Governorate during 2014 and 2015 growing seasons to evaluate the impact of irrigation levels i.e.,120, 100, 80 and $60 \%$ of the evapotranspiration (ETc) and stress alleviation substances (seaweed extract, potassium silicate and abscisic acid against control treatment) on growth, corm yield and quality of taro (Colocasia esculenta cv. Balady), with a particular attempt to establish irrigation water strategy for taro cultivation. The results indicated a reduction in plant growth and corm yield as well as quality due to minimizing irrigation level from 120 to $60 \%$ ETc. But the highest water use efficiency (WUE) was obtained with $80 \%$ irrigation level. Seaweed extract showed a superior enhancement in all measured vegetative, yield and quality parameters followed by potassium silicate compared to abscisic acid or control. Seaweed extract heightened the WUE compared to other substances. Results concluded that using $80 \%$ irrigation level accompanied by spraying plants with seaweed extract led to a mild reduction in the plant growth, yield and quality but conferred the higher WUE compared to other interactive treatments.
\end{abstract}

Keywords: Taro, vegetative growth, Deficit irrigation, Stress alleviation substances, Seaweed extract, Potassium silicate, Abscisic, Corm yield, Water use efficiency.

\section{INTRODUCTION}

Taro [Colocasia esculenta (L.) Schott] is grown throughout the humid tropics and subtropics areas (Matthews et al 2017). Moreover,taro is considers a valuable source of essential mineral nutrients (Mergedus et al 2015) and is high in fiber, vitamins A, C, E and B6 (Wills et al 1983; Lebot and Lawac, 2017). According to the FAO definition (FAO, 1994), taro is the $5^{\text {th }}$ crop between the main six crops that accumulate starch in roots, tubers, rhizomes, corms and stems which commonly consumed as human and animal food, and as manufactured food products. Meanwhile, it needs high water requirements thus shows least water use efficiency (Uyeda et al 2011; Ganança et al 2018).

Shortage the freshwater quantity devoted to the agriculture in Egypt made the researchers looking for policies and/or practices to maximize the water use efficiency or water productivity. Meanwhile, the insistence on taro cultivation, semi-aquatic plant, consumes a plenty of water so it becomes imperative to adopt agricultural policies use less water for continuing taro cultivation without reducing its area. Howell (2001) reported that the main pathway for enhancing the water use efficiency in irrigation agriculture concentrate on engineering and agronomic management aspects. These approaches for using less water were reported by Evans and Sadler (2008) as deficit irrigation, efficient irrigation systems such as sprinkler and drip irrigation systems, covering soil surface (mulching) as well as 
agronomic practices as conservation tillage, defoliation and spraying anti-stress and antitranspiration substances (El-Zohiri and Abd Elal, 2014; Abu El-Azm and Youssef, 2015).

Due to the shortage of the available information on a success of applying irrigation systems other than the furrow irrigation as a popular irrigation system for taro irrigation in the areas of Nile valley and delta, applying drip irrigation system in taro cultivation, as a higher efficient irrigation method, in loamy and clay soils could be accompanied by certain stresses on the plant especially under deficit irrigation. Therefore, this work was designed to investigate utilizing deficit irrigation for water conservation and avoiding the potential deleterious effect on taro plants using spraying stimulation substances.

\section{MATERIALS AND METHODS}

Experimental site and plant materials: The field experiment was conducted during 2014 and 2015 growing seasons at the Experimental Farm of the Horticultural Research Station of Barrage, Qalyubia Governorate, Egypt. According to soil analysis results Table (1) soil texture of the experimental site was a clay. The taro cultivar used for this study was a local cultivar (Balady) which is the common cultivar in Egypt. The planting dates were on 10 and $15^{\text {th }}$ of March, in the first and second seasons, respectively.

Table 1. The physical and chemical properties of the experimental soil.

\begin{tabular}{|c|c|c|c|c|c|c|c|c|c|}
\hline \multicolumn{10}{|c|}{ Physical properties } \\
\hline \multicolumn{2}{|c|}{ Sand } & \multicolumn{3}{|c|}{ Silt \% } & \multicolumn{2}{|c|}{ Clay \% } & \multicolumn{3}{|c|}{ Texture } \\
\hline \multicolumn{2}{|c|}{30.67} & \multicolumn{3}{|c|}{22.74} & \multicolumn{2}{|c|}{46.59} & \multicolumn{3}{|c|}{ Clay } \\
\hline \multicolumn{10}{|c|}{ Chemical properties } \\
\hline \multicolumn{10}{|c|}{ Soluble ions in saturated extract, (meq/l) } \\
\hline $\begin{array}{c}\mathrm{EC} \\
\mathrm{dS} / \mathrm{m}\end{array}$ & $\mathrm{pH}$ & $\mathrm{HCO}_{3}^{-}$ & $\mathrm{Cl}^{-}$ & $\mathrm{SO}_{4}^{-}$ & $\mathrm{Ca}^{++}$ & $\mathrm{Mg}^{++}$ & $\mathrm{Na}^{+}$ & $\mathrm{K}^{+}$ & \\
\hline 0.19 & 8.30 & 0.89 & 0.5 & 0.51 & 0.26 & 0.34 & 0.70 & 0.6 & \\
\hline
\end{tabular}

Experimental treatments and design: The experiment involved four irrigation levels $(60,80,100$ and $120 \%$ of the crop evapotranspiration ETc) applied through drip irrigation system. The irrigation levels were calculated using FAO-CROPWAT software version 8 to calculate the crop irrigation water requirements based on the reference crop evapotranspiration as described by PenmanMonteith which has now become the standard for estim ating reference crop evapotranspiration (Smith and Steduto, 2012). Evapotranspiration was calculated according to the water balance approach as described by James (1995). The irrigation treatments were applied after 60 days from planting then continued until harvesting. The second factor was plant stimulant substances which were seaweed extract $(1.5 \mathrm{~g} / \mathrm{l})$ in a powder form, potassium silicate $(2 \mathrm{~g} / \mathrm{l})$ in a powder form and abscisic acid (30 ppm) in a trading form (proton) involved 10 abscisic acid as well as spraying distilled water as a control treatment. The plant stimulant substances were sprayed after two months from planting date and repeated every two weeks.

The experimental design was a split-plot with four replications. The irrigation levels were distrib- uted randomly in the main plots. Meanwhile, the four plant stimulant substances were randomly distributed in the subplots. Each subplot composed of five rows with row width of $80 \mathrm{~cm}$ and row length of $5 \mathrm{~m}$.

Cormels with the same weights of about $100 \mathrm{~g}$ were used as planting materials and were planted at $25 \mathrm{~cm}$ spacing in one line along the row. Cultivation and all cultural practices other than irrigation (fertilization, weeding, and pest control) were performed according to the recommendations of the Egyptian Ministry of Agriculture, were kept normal and uniform for all the treatments.

\section{Data recorded:}

A random sample of five plants from the three inner rows of each experimental plot were taken at the harvest (270 days after the planting date) and the vegetative growth data were recorded. Plant height was measured from the ground level to the top point of plant. Also, the standing leaves on each individual plant were counted, and average leaf area was estimated. In the mid growing season, total chlorophyll content of five leaves was 
determined by using Minolta SPAD-502 Chlorophyll Meter (MINOLTA CO., LTD. Japan). The same leaves were dried at $70 \mathrm{C}^{\circ}$ to constant weight then leaf dry matter was estimated according to the following formula:

Leaf dry matter percent $=($ dry weight of leaves / fresh weight of leaves) $x$ 100. Also the dried leaves from each sample was subjected to measuring the nutrients. Nitrogen percent was measured determined according to Kock and Mc Meckin (1924). Phosphorus percent was measured calorimetrically at the wave length $680 \mathrm{~nm}$ using Spectrophotometer device (UV/VIS Spectrophotometer, CT 200) as described by Troug and Meyer (1939).

Potassium percent was measured via flame photometer device as mentioned by Brwon and Lilliland (1946). Also, calcium percent was measured through Flame photometer device according to the method described by Chapman and Pratt (1961). Magnesium contents was determined using atomic absorption spectrophotometer according to A.O.A.C. (2000).

All corms from the three inner rows of each experimental plot were harvested. Corms were cleaned from the residual of soil and the corm weight and yield/ feddan were calculated. Water use efficiency (WUE) was calculated as the units of total yield produced from each unit volume of the used water ( $\mathrm{kg}$ yield $/ \mathrm{m}^{3}$ water).

$$
W U E \text { = } \frac{\text { Crop yield kg/fed. }}{\text { water (m3/fed.) }}
$$

Corm samples were dried to constant weight at $70^{\circ} \mathrm{C}$ for dry matter determination. Carbohydrates and starch content in corms were determined according to A.O.A.C. (2000).

Data analysis: All data were subjected to the analysis of variance with SAS statistical package [15]. Means of main effects and interactions were separated using least significance difference (LSD). All statistical determinations were made at $P=0.05$.

\section{RESULTS AND DISCUSSION}

\section{Vegetative growth parameters}

Data in the Table (2) revealed that number of leaves and chlorophyll reading recorded descending values against decreasing irrigation levels during the two growing seasons. However, plant height, leaf area and leaf dry matter percent in the first season, irrigation levels of $80 \%$ and $100 \%$ showed no significant differences in the remain parameters. On the other hand, the least values of all parameters were recorded with $60 \%$ irrigation level. Al-Mansor et al (2015) and Abdelhady et al (2017) established their experiments under the same area and climate and concluded that the irrigation level $80 \%$ of the crop evapotranspiration (ETc) or more maintained soil moisture in the readily available water range. Therefore, the impact of these irrigation levels on the crop behavior mostly was not significant. Meanwhile, under this investigation, $120 \%$ irrigation level was the best treatment in improving the vegetative performance of taro due to the higher water requirement of the plant (Bussell and Bonin, 1998). Where taro growth and yield of corms were improved well under the higher level of the irrigation (El-Zohiri and Abd Elal, 2014). On the other hand, applying deficit irrigation in taro clearly decrease vegetative growth so reflected negatively on the corm yield (El-Zohiri and Abd Elal, 2014).

Foliar sprayed seaweed extract conferred the superior improvement of all vegetative parameters followed by potassium silicate compared to abscisic acid or control. Meanwhile, leaf dry matter percent was not significantly affected by all the sprayed substances. These results were true in the two growing seasons.

For the interaction between irrigation levels and foliar sprayed substances, the effect of irrigation on the taro vegetative growth parameters was stronger than the foliar sprayed substances. So all measured parameters showed descending values with decreasing the irrigation levels even under the same foliar sprayed substance. Nevertheless, spraying seaweed extract on the taro plants still the best treatment under each irrigation level followed by potassium silicate but sometimes spraying abscisic acid decreased the measured parameters values than control treatment. It is worth noting that the measured parameters values were similar when spraying seaweed extract under both $80 \%$ and $100 \%$ irrigation levels. The data was consistency during the two seasons.

Based on the explained data, under reduction irrigation levels the used substances varied in its stimulation effect where seaweed extract was more effective in attenuating the adverse effect of reduction irrigation level meanwhile abscisic acid sometimes exhibited more reduction effect than control. 


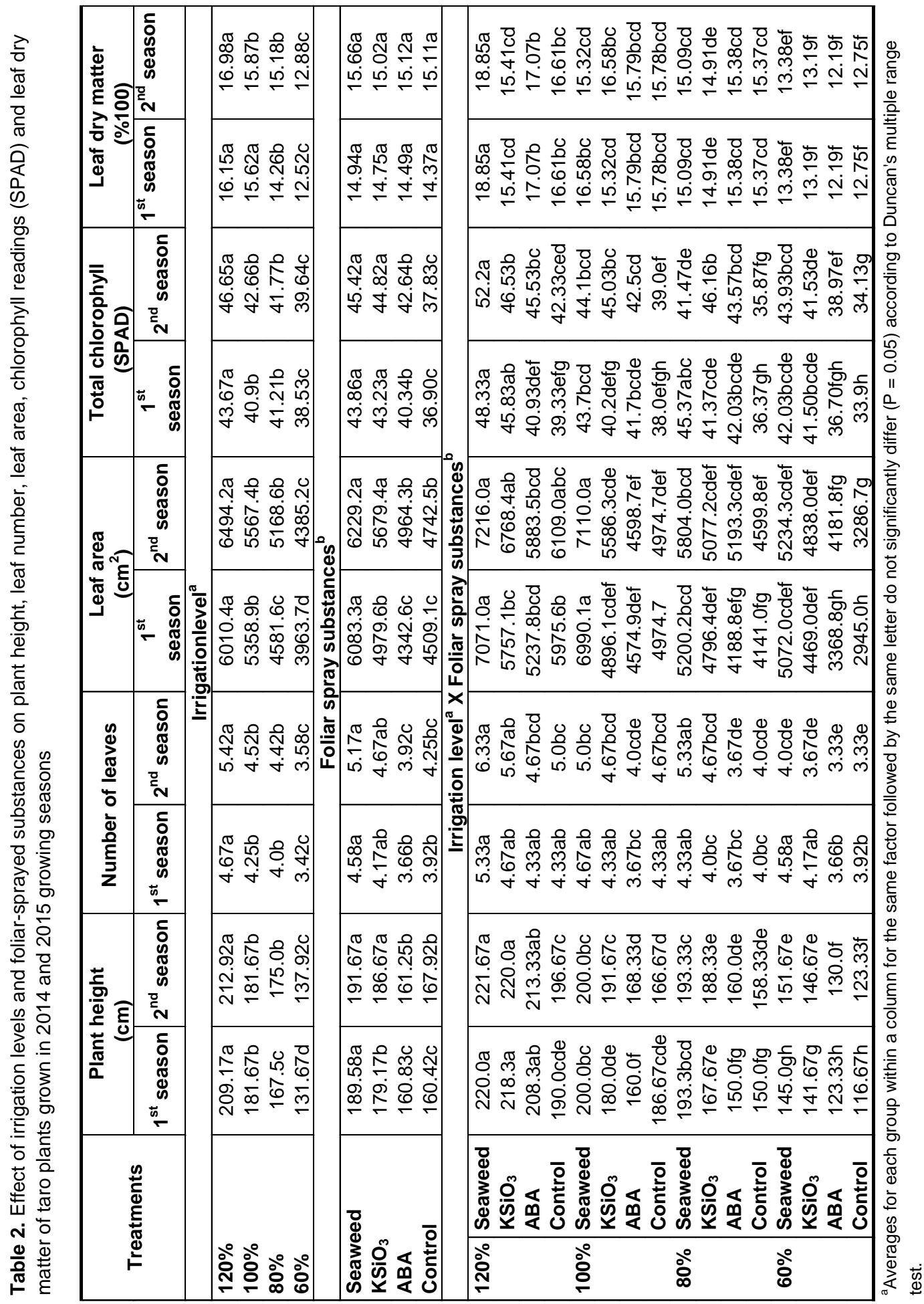



Silicate and abscisic acid on growth corm yield and quality of taro

Deficit irrigation as saving irrigation water strategy, at least under the Egyptian conditions where shortage of fresh water for irrigation, is a must. According to Abu El-Azm and Youssef (2015) and Abdelhady et al (2017), applying deficit irrigation led to a certain stress on the plant depending on the stress severity. However, many agronomic practices could be carried out to alleviate the drought stress as using more efficient irrigation method mainly drip irrigation and applying stress alleviator substances (El-Zohiri and Abd Elal, 2014; Abu El-Azm and Youssef, 2015; Abdelhady et al 2017). In this work seaweed extract, potassium silicate and abscisic acid were used to attenuating the negative effect of the drought stress. Abscisic acid showed a poor stress alleviating effect but sometimes led to increasing the drought stress effect because of abscisic acidmediated the drought stress response where abscisic acid closes the stomata (Hetherington and Woodward 2003). Stomatal closure results in a reduction of stomatal conductance and $\mathrm{CO}_{2}$ availability, which reduces rates of photosynthesis (Chaves et al 2003). Meanwhile, the seaweed extract showed a superior effect in drought stress alleviation where it was used in numerous studies for nutrient supplementation and as biostimulant or biofertilizer to increase plant growth and yield (Blunden et al 1997). Also other studies have revealed a wide range of other beneficial effects of seaweed extract applications on plants, such as improve plant performance and yield, elevated resistance to biotic and abiotic stress, and other benefits in the plant production (Khan et al 2009; Abu Seif et al 2016; Ertani et al 2018). As described by Blunden et al (1997), the application of seaweed extract increased chlorophyll content, improved photosynthesis and nutrient uptake so, under our work, seaweed foliar spray enhanced taro plant performance $($ Tables 2,3 ) especially leaf chlorophyll content and nutrients uptake particularly under low irrigation levels. This effect was accompanied by a clear improvement in the plant height, number of leaves, leaf area and leaf dry matter. Abu El-Azm and Youssef (2015) cited that the stimulus effect of potassium silicate my be due to the role of both potassium and silicon in plant growth, especially under stresses. Where potassium plays important roles in alleviating the damaging effects of drought stress through its effects on enzyme activation, protein synthesis, photosynthesis, stomatal movement and water-relation (turgor regulation and osmotic adjustment) in plants (Marschner, 2011). Moreover, the beneficial roles of silicon in combating various biotic and abiotic stresses have been widely reported (Zhu and Gong, 2014). Under our study, the enhancing effect of potassium silicate either as absolute or combined with irrigation was less than that of seaweed, especially under less watering.

\section{Mineral content in the leaves}

Data in Table (3) exhibited that nitrogen, phosphorus, potassium, calcium and magnesium content in taro leaves were decreased with decreasing the irrigation level. The highest values of the nutrients content were recorded with the irrigation level of $120 \%$ of the ETc while the least values were recorded with $60 \%$ ETc irrigation level. The highest content of nitrogen, phosphorus, potassium, calcium and magnesium in taro leaves were achieved with seaweed extract foliar spraying followed by spraying with potassium silicate, while no significant differences were recorded with abscisic acid spraying or control treatment. The interaction between irrigation levels and foliar spray substances affected significantly the nutrients content in taro leaves. It is clear that seaweed extract spraying modified the adverse effect of decreasing the irrigation levels than spraying with either of potassium silicate or abscisic acid.

\section{Corm yield and water use efficiency}

Data in Table (4) revealed that corm yield per feddan was significantly affected by irrigation level, foliar spray substances and their interaction. Due to the synchronization of vegetative growth and corm formation in taro, corm yield was also affected by the experimental factors similarly to the vegetative growth. Where the highest corm yield was obtained with higher irrigation level. In other words, corm yield was positively correlated by the amount of irrigation water. 


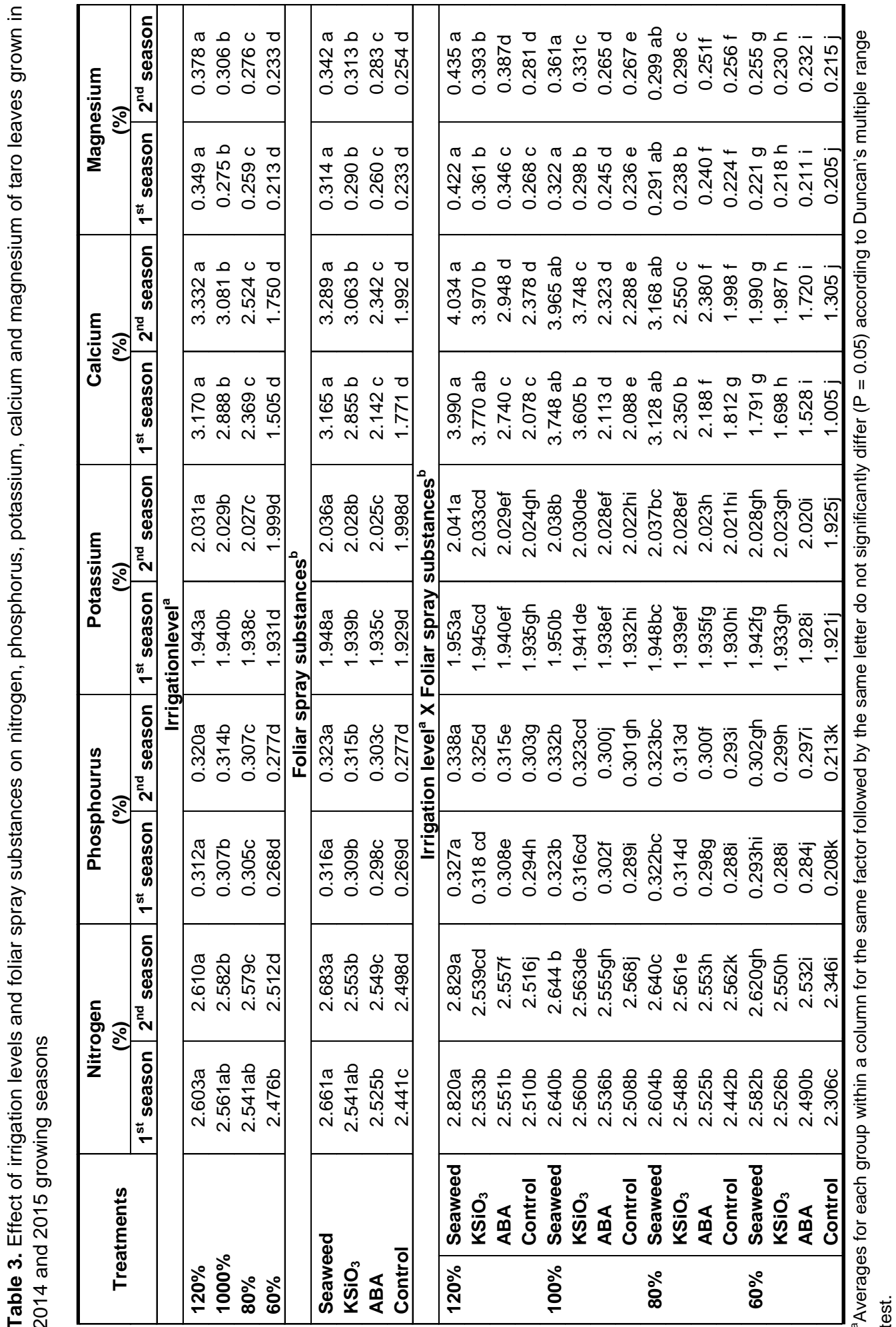


Table 4. Effect of irrigation levels and foliar spray substances on yield and water use efficiency of taro grown in 2014 and 2015 growing seasons

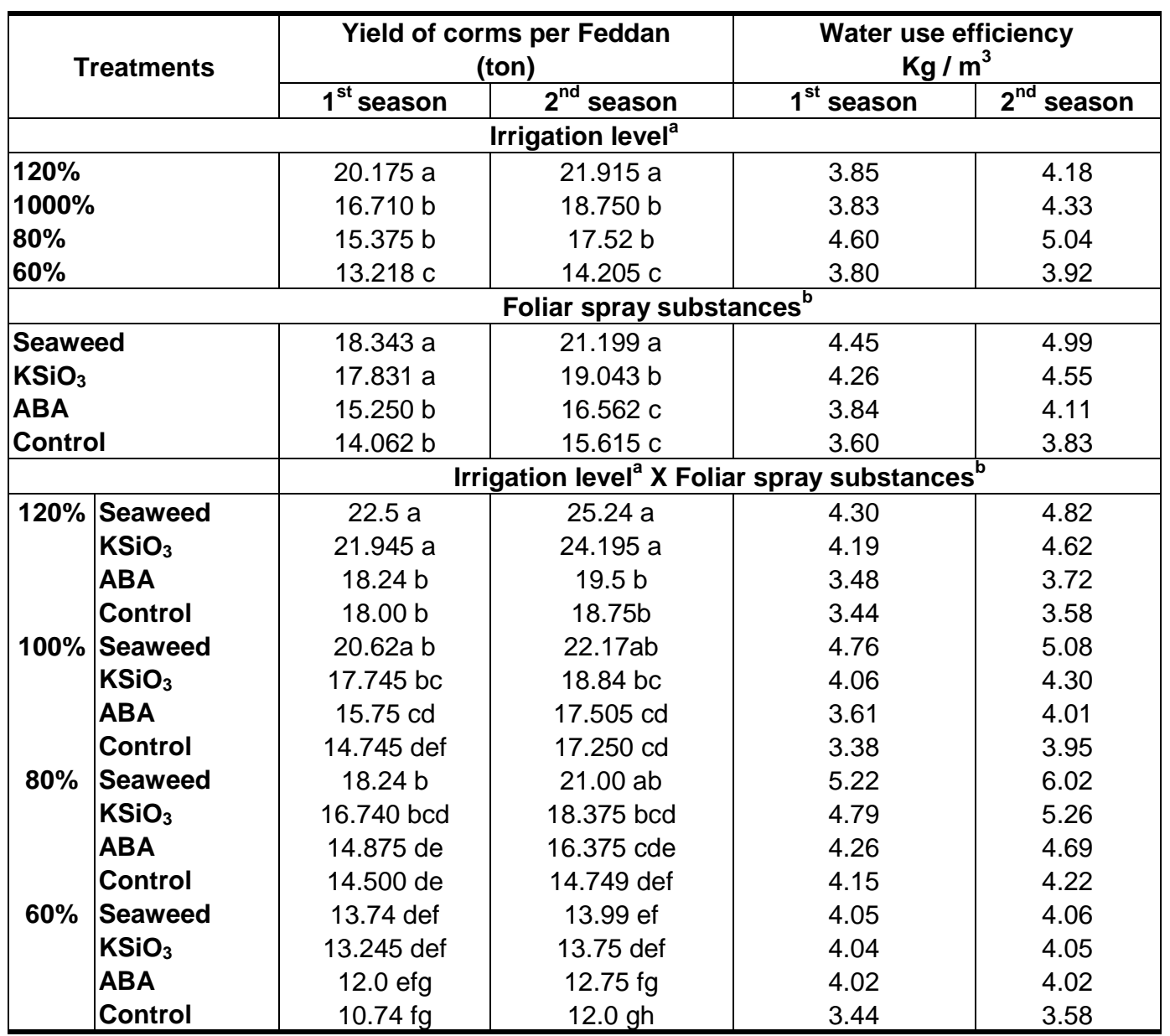

${ }^{a}$ Averages for each group within a column for the same factor followed by the same letter do not significantly differ $(P=0.05)$ according to Duncan's multiple range test.

For the impact of foliar spray substances (seaweed extract, potassium silicate and abscisic acid) it was observed that substances increased corm yield than control treatment. The highest corm yield was recorded with seaweed followed by potassium silicate then abscisic acid.

Regarding the effect of the interaction between irrigation level and foliar spray substances, results it is appered that at $120 \%$ ETc irrigation level, both seaweed extract and potassium silicate were superior and equally in their effect on the corms yield. But with the lower irrigation levels, seaweed extract was still superior to other substances with all irrigation levels. Abscisic acid, especially under low irrigation levels, showed no enhancing effect but it might increase the adverse effect of irrigation level reduction.
Water use efficiency is considered a true criterion for distinguishing between the experimental treatments. Therefore, the highest WUE was obtained with $80 \%$ irrigation level. Seaweed extract foliar spray recorded the highest WUE compared to other used substances. The combination of seaweed and $80 \%$ irrigation level conferred the surpassed WUE than other combinations. These results were true during the two growing seasons.

\section{Corm quality}

Fresh weight, dry matter percent and carbohydrates and starch percent in taro corm responded significantly to irrigation levels (Table 5). The response was compatible with irrigation level. Where 


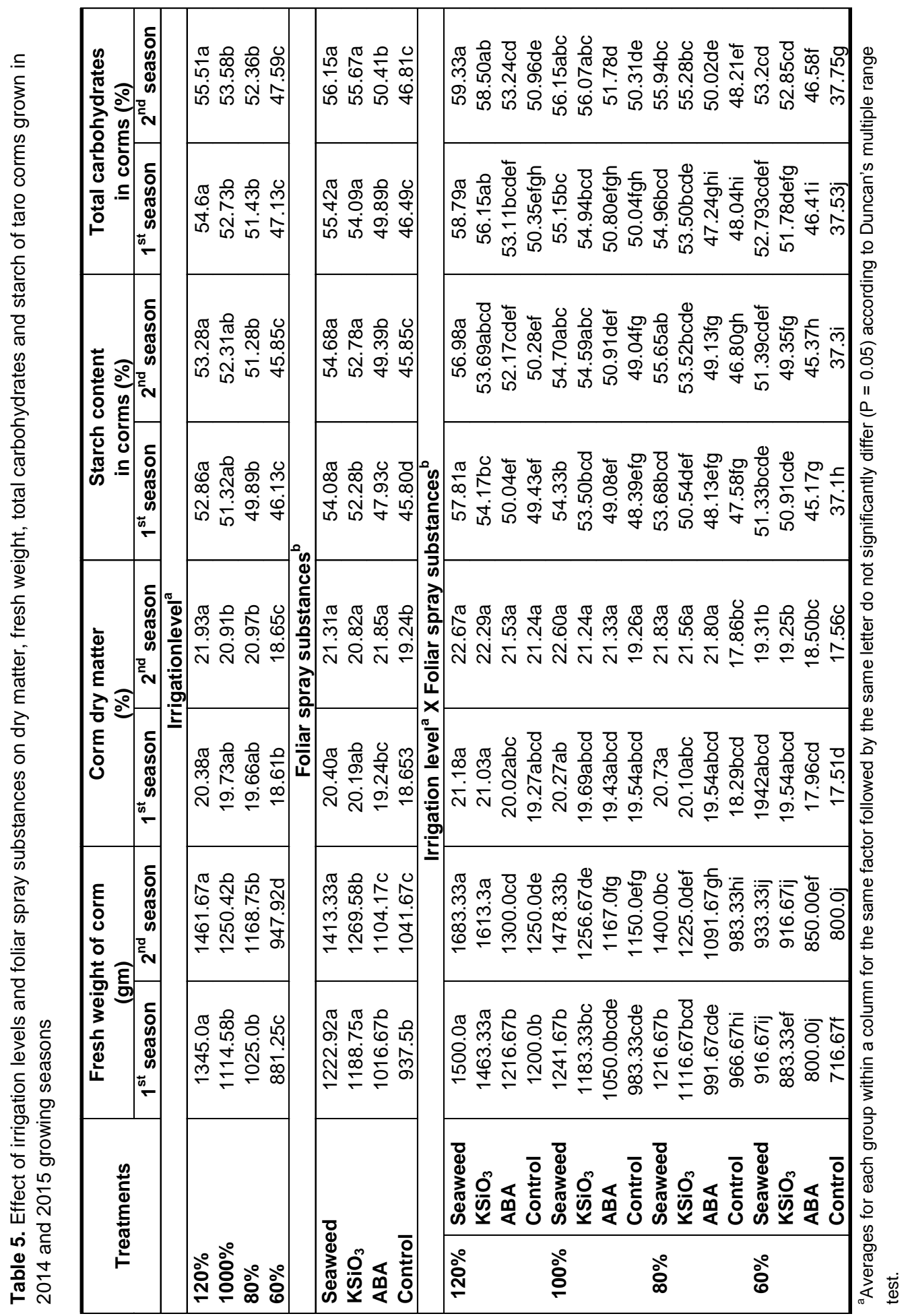


the highest values of all parameters were obtained with $120 \%$ irrigation level then the values were decreased with decreasing the irrigation level to $60 \%$ of the ETc.

It was clear that the foliar spray with seaweed extract was superior, thereafter potassium silicate, but the least values of the corm parameters were recorded by abscisic acid or control treatments.

Taro corm parameters were significantly affected by the interaction between irrigation levels and foliar spraying substances. The irrigation levels exhibited a clear effect compared to the foliar spraying substances because of the descending response of the corm parameters to each foliar spraying substance with decreasing the irrigation level.

Corm parameters values were similar when spraying seaweed extract with each irrigation levels of $80 \%$ and $100 \%$, the same result was obtained by spraying potassium silicate. The same trend of data was obtained during the two growing seasons starch content in the corm showed the highest values under each $100 \%$ and $120 \%$ irrigation levels compared to irrigation levels of $80 \%$ and $60 \%$ of the ETc. Taro vegetative growth and corms formation (yielding) are synchronized. So that, according to Paul and Bari (2011) vegetative growth indicating to corms yield and quality. Therefore, our results demonstrated that higher corm yield and quality (corm fresh and dry weight as well as starch and carbohydrate contents) appeared to be concomitant with irrigation levels $(120 \%$ and $100 \%$ ETc) and foliar spry substances (seaweed extract and potassium silicate) and their combinations which also enhanced the vegetative growth parameters.

\section{CONCLUSION}

Taro cultivation in Egypt earns an important situation especially in some areas. Therefore, the result of this study support continuing taro production even under the fresh water shortage with some modifications in the irrigation system and agronomic practices. So using drip irrigation as a higher efficient irrigation method is preferable and increases water use efficiency. Otherwise, minimizing the irrigation water quantity by about $20 \%$ can heighten the water use efficiency but may cause a drought stress on the plants which could be attenuated via foliar spraying mainly by seaweed extract and alternatively by potassium silicate.

\section{REFERENCES}

Abdelhady S.A., AbuEl-Azm N.A.I. and El-Kafafi E.H. 2017. Effect of deficit irrigation levels and NPK fertilization rates on tomato growth, yield and fruits quality. Middle East J. of Agric. Research, 6(3), 587-604.

Abu El-Azm N.A.I. and Youssef S.M.S. 2015. Spraying potassium silicate and sugar beet molasses on tomato plants minimizes transpiration, relieves drought stress and rationalizes water use. Middle East J. Agric. Research, 4(4), 1047-1064.

Abu Seif Y.I., El-Miniawy S.M., Abu El-Azm N.A. I. and Hegazi A.Z. 2016. Response of snap bean growth and seed yield to seed size, plant density and foliar application with algae extract. Annals of Agric. Sci., 61(2), 187-199.

Al-Mansor A.N., El-Gindy A.M., Hegazi M.M. ElBagoury K.F. and Abd El-Hady S.A. 2015. Effect of surface and subsurface trickle irrigation on yield and water use efficiency of tomato crop under deficit irrigation conditions. Misr J. Ag. Eng., 32(3), 1021- 1040.

A.O.A.C. 2000. Official Methods of Analysis. $17^{\text {th }}$ Ed., Association of Official Chemists. Washington DC., USA.

Blunden G., Jenkins T. and Liu Y.W. 1997. Enhanced leaf chlorophyll levels in plants treated with seaweed extract. J. of Applied Phycology $8,535-543$.

Brown J. and Lilliland O. 1946. Rapid determination of potassium and sodium in plant material and soil extracts by flame photometric. Proc. Amer. Soc. Hort. Sci., 48, 341-346.

Bussell W. and Bonin M. 1998. Effects of high and low watering levels on growth and development of taro. New Zealand J. of Crop and Horticultural Sci., 26, 313-317.

Chapman H.D. and Pratt P.F. 1961. Methods of Analysis for Soils, Plants and Waters. Priced Publication 4034. Division of Agric. Sci., Univ., of California, Berkeley, $62 \mathrm{p}$.

Chaves M.M., Maroco J.P. and Pereira J.S. 2003. Understa+nding plant responses to drought-from genes to the whole plant. Functional Plant Biology 30, 239-264.

El-Zohiri S.S.M. and AbdElal A.M.H. 2014. Improve the adverse impacts of water stress on growth, yield and its quality of taro plants by using glycinebetaine, $\mathrm{MgCO} 3$ and defoliation under Delta conditions. Middle East J. of Agric. Research, 3(4), 799-814. 
Ertani A., Francioso O., Tinti A., Schiavon M., Pizzeghello D. and Nardi S. 2018. Evaluation of seaweed extracts from Laminaria and Ascophyllum nodosum spp. as biostimulants in Zea mays L. using a combination of chemical, biochemical and morphological approaches. Frontiers in Plant Sci., 9, 428-438.

Evans R.G. and Sadler E.J. 2008. Methods and technologies to improve efficiency of water use. Water Resour. Res., 44, 1029-1032.

FAO, 1994. Definition and classification of commodities: roots and tubers and derived Products.

Ganança J., Freitas J., Nóbrega H., Rodrigues V., Antunes G., Gouveia, C., Rodrigues M., Chaïr H., Pinheiro de Carvalho M. and Lebot V., 2018. Screening for drought tolerance in thirty-three taro cultivars. Notulae Botanicae Horti Agrobotanici Cluj-Napoca, 46(1), 6574.

Hetherington A.M. and Woodward F.I. 2003. The role of stomata in sensing and driving environmental change. Nature 424, 901-908.

Howell T. A. 2001. Enhancing Water Use Efficiency in Irrigated Agriculture. Agron. J. 93, 281289.

James C.S. 1995. Analytical chemistry of foods. Blokie Academic \& Proffessional, London, pp. 150-173.

Khan W., Rayirath U.P., Subramanian S., Jithesh M.N., Rayorath P., Hodges D.M., Critchley A.T., Craigie J.S., Norrie J., and Prithiviraj B. 2009. Seaweed extracts as biostimulants of plant growth and development. J. Plant Growth Regul 28, 386-399.

Koch F.C. and McMeckin T.L.1924. A new direct nasalization micro. Keldahl method and a modification of the Nessler-Folin reagent for ammonia . J. Amer. Soc. Chem., 46, 2066-2069.

Lebot V. and Lawac F. 2017. Quantitative comparison of individual sugars in cultivars and hybrids of taro [Colocasia esculenta (L.) Schott]: implications for breeding programs. Euphytica 213, 147-155.

Marschner H. 2011. Marschner's Mineral Nutrition of Higher Plants. 3rd Ed. Academic Press, San Diego, California, USA, 672 p.

Matthews P.J., Lockhart P.J. and Ahmed I. 2017. Phylogeography, ethnobotany and linguistics issues arising from research on the natural and cultural history of taro, Colocasia esculenta (L.) Schott. Man India 97(1), 353380.

Mergedus A., Kristl J., Ivancic A., Sober A., Sustar V., Krizan T. and Lebot V. 2015. Variation of mineral composition in different parts of taro (Colocasia esculenta) corms. Food Chem., 1(170), 37-46.

Paul K.K. and Bari M.A. 2011. Studies on direct and indirect effects of different plant characters on yield of taro (Colocasia esculenta L. Schott) Var. Antiquorum. The Agric. 9(1\&2), 89-98.

Smith M. and Steduto P. 2012. Yield response to water: the original FAO water production function. FAO Irrigation and Drainage, 66 p., FAO: Rome, Italy, 5, 6-12

Troug E. and Meyer. 1939. Improvement in denies calorimetric method for phosphorus and arsenic. Indian English Chemistry Analysis Edition, 1, 136-139.

Uyeda J., Radovich J.K., Sugano J., Fares A. and Paull R. 2011. Effect of irrigation regime on yield and quality of three varieties of taro (Colocasia esculenta). Food Provider, MayApril, 2011. pp. 1-3.

Wills R.B.H., Lim J.S.K., Greenfield H. and Bayliss-Smith T. 1983. Nutrient composition of taro (Colocasia esculenta) cultivars from the $\mathrm{Pa}$ pua New Guinea highlands. J. Sci. Food and Agric., 34, 1137-1142.

Zhu Y.X. and Gong H.J. 2014. Beneficial effects of silicon on salt and drought tolerance in plants. Agron. Sustain. Dev., 34(2), 455472. 
مجلة اتحاد الجامعات العربية للعلوم الزراعية ، جامعة عين شمس ، القاهرة

مجلد(26)، عدد(2D)، عدد خاص ، 2285-2275، 2019

Website: http://strategy-plan.asu.edu.eg/AUJASCI/

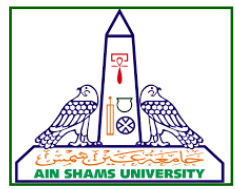

2285

تأثير مستويات الرى والرش الورقى بمستخلص الاعثاب البحرية وسيليكات البوتاسيوم وحمض الابسيسك على النمو ومحصول الكورمات وجودة القلقاس

[165]

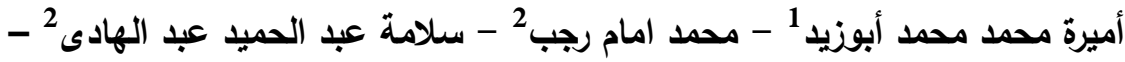

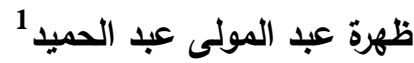

1- قسم بحوث البطاطس و الخضر خضرية التكاثر - معهد بحوث البساتين - مركز البحوث الزراعية- الجيزة - مصر

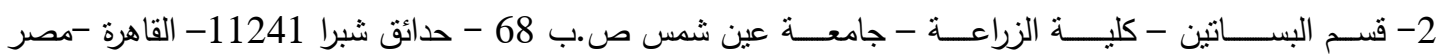

*Corresponding author: amiromay@yahoo.com

Received 4 July, 2018

Accepted 22 July, 2018

80٪. أظهر مستخلص الأعشاب البحرية تحسينًا فائقًا

في جميع القياسات الخضرية والمحصول والجودة التئة

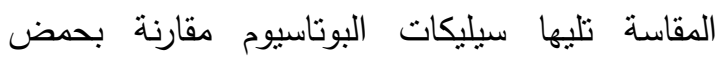

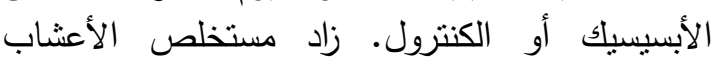

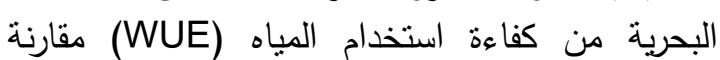

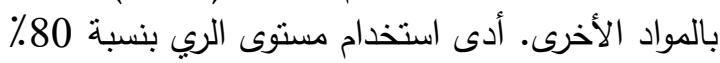

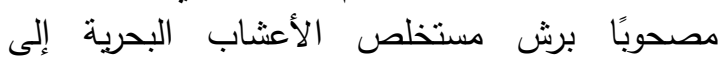
انخفاض معتدل في نمو النبات والمحصول والجودة، الابلة ولكنه أعطى أعلى مستوى لكفي نهاءة استخدام المياه

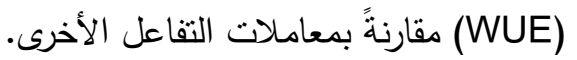

الكلمات الدالة: القلقاس، النمو الخضرى، نقص مستوى

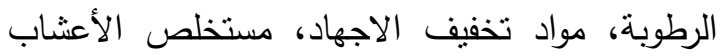

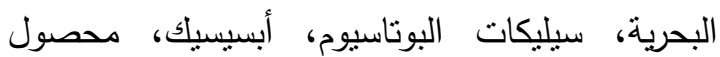
الكورمات، كفاءة استخدام الماء التباء

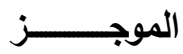

أقيمت تجربة حقلية فى المزرعة البحثية لمعهد بحوث البساتين بمحطة القناطر فى محافظة القليوبية

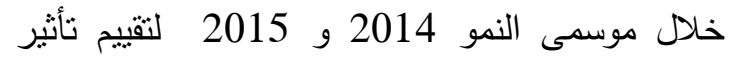
مستويات الرطوبة (120\% 100، 100، 80، 60 من 60 من

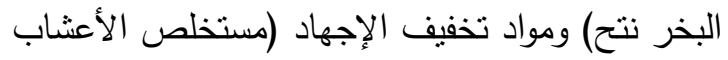

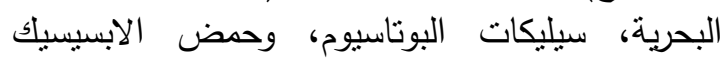

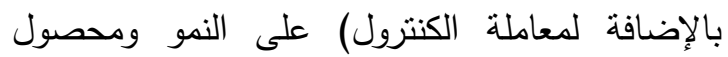
الكورمات وجودة القلقاس البلدى مع محاولة لتطبلة لتطبيق

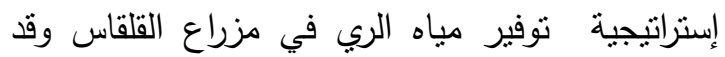

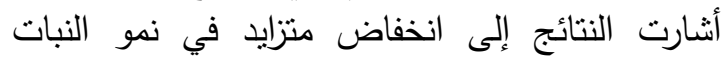

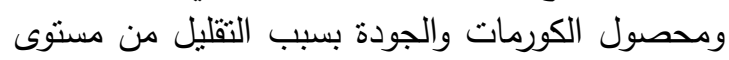

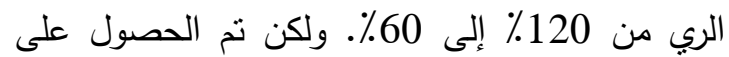
أعلى كفاءة استخدام للمياه (WUE) مع مستوى الري 

